\title{
Institutional Innovation by the Asian Infrastructure Investment Bank
}

\author{
James RANSDELL* \\ United States Court of International Trade, United States of America \\ jimransdell@gmail.com
}

\begin{abstract}
The Asian Infrastructure Investment Bank [AIIB] is the world's newest multilateral development bank [MDB] and already one of Asia's largest international organizations by membership. This paper will compare the institutional structure of the AIIB with that of the Asian Development Bank [ADB] to identify areas in which the AIIB has innovated as a matter of international institutional law. In reviewing the constituent documents, bylaws, and operational policies of the two banks, the paper will juxtapose the AIIB and ADB's approaches to membership, project finance, voting, and governance. It will identify not only innovations, but also the likely implications, positive and negative, thereof. Finally, it will assess the degree to which these innovations may impact the AIIB's ability to partner with existing MDBs. In particular, the AIIB's approach to project finance and governance mark a significant break from the status quo, while in other areas it has remained conservative.
\end{abstract}

The Asian Infrastructure Investment Bank [AIIB] is the newest multilateral development bank [MDB]. Politically, it was a Chinese-initiated endeavour, though Chinese grievances with incumbent MDBs largely reflected broader dissatisfaction among borrower countries. There was accordingly much discussion of the AIIB's potential to adopt institutional structures with wider appeal, and perhaps challenge the nowdominant Bretton Woods model. This paper will assess the degree to which the AIIB, through its first year of operation, has pursued such innovation as a matter of international institutional law.

On 25 December 20I5, nearly fifty years after the US and Japanese-led Asian Development Bank [ADB] was created, the AIIB Articles of Agreement [AIIB Agreement] entered into force. The AIIB had fifty-seven "founding members", fifty-four of which have since ratified the AIIB Agreement, whereas the ADB counts sixty-seven full members. Despite considerable political and economic analysis of the AIIB, and

Law Clerk to the Hon. Jane A. Restani, United States Court of International Trade. I wish to thank Professor Dr Neils M. Blokker for his guidance in constructing the thesis from which this paper was derived. The paper was prepared in the author's personal capacity. All views expressed herein are the author's own and do not represent the view of any US government entity. 
extensive speculation regarding China's motives, institutional law analysis has been limited. Yet, the creation of a \$roobn multilateral organization is certainly a noteworthy development in the international legal landscape, even more so as the AIIB was initiated entirely by non-Western states. Western contributions have largely focused on governance and lending standard concerns. ${ }^{\text {I }}$ Asian scholarship has been more multifaceted, but language barriers render it less accessible to Western audiences. $^{2}$

The AIIB enters a crowded field, including twenty-eight MDBs and many more bilateral development banks. ${ }^{3}$ It was only the second MDB founded since the European Bank for Reconstruction and Development in $\mathrm{I} 99 \mathrm{I},{ }^{4}$ leaving decades of experience which could inform institutional improvements. This paper will compare the contemporary institutional structures of the AIIB and ADB. These banks are juxtaposed for three reasons: (I) geographic similarity-both the region of operation and membership are similar; 5 (2) representativeness-like most existing MDBs, the ADB's institutional structure was closely modelled on the World Bank [WB], ${ }^{6}$ whereas the AIIB better represents recent MDB initiatives than the BRICS New Development Bank, due to the latter's comparatively limited membership and slow lending; ${ }^{7}$ and (3) lending portfolio similarity-despite its broader overall focus, much of the ADB's lending focuses on infrastructure, the lifeblood of the AIIB. ${ }^{8}$ Whereas the ADB has decades of experience, however, the AIIB has just drafted certain operational policies. This imbalance makes certain comparisons difficult, but since many grievances with

I. Exceptions include: Stephany GRIFFITH-JONES, Xiaoyun LI, and Stephen SPRATT, "The Asian Infrastructure Investment Bank” (20I6) Institute of Development Studies Evidence Report No. I79; Helmut REISEN, "Will the AIIB and the NDB Help Reform Multilateral Development Banking?” (20I 5 ) 6 Global Policy 297; Ming WAN, The Asian Infrastructure Investment Bank (New York: Palgrave Macmillan, 20I6) at 58-9I (comparing each bank upon its founding).

2. See e.g. Jianfeng LIU and Yingli PAN, “AIIB’s Advantages and Challenges” Shanghai Economic Review (I9 May 20I 5); Jian WANG, "AIIB Creates a New Model for South-South and North-South Cooperation" Shanghai Economic Review (I9 May 20I 5 ) ; Yan LI and Zhi-hong WAN, "A Study on Sustainable Development at the AIIB: Comparative Analysis of MDBs” (2015) 6 Asia-Pacific Economic Review 23.

3. Phillip Y. LIPSCY, "Explaining Institutional Change" (20I 5 ) 59 American Journal of Political Science 34I.

4. Rebecca M. NELSON, "Multilateral Development Banks" Congressional Research Service Report R4II70 (2 December 20I 5) at 3. In July 20I4, Brazil, Russia, India, China, and South Africa signed the Agreement on the New Development Bank. Ibid., at I7. Agreement on the New Development Bank (20I5).

5. The AIIB's "region" is that "classified as Asia and Oceania by the United Nations". AIIB, "Report of the Chief Negotiators on the Articles of Agreement of the Asian Infrastructure Investment Bank" (22 May 20I 5), art.I(2) [Chief Negotiators' Report]; AIIB Agreement, art.I(2). The ADB's “region" encompasses the terms of reference for the UN Economic Commission for Asia and the Far East. ADB Charter, art.I. Comparing AIIB and ADB membership rosters at the AIIB's time of founding, noteworthy differences arise. Geographically, the AIIB had more members from Central Asia and the Middle East, whereas the ADB counted more Southeast Asian and Oceanian members. Geopolitically, fellow BRIC states supported China's initiative, whereas India and China are the only BRIC states in the ADB. The US and Japan declined to join the AIIB. Both banks' European participants were roughly the same.

6. Chris HUMPHREY, "He Who Pays the Piper Calls the Tune" (20I7) I 2 Review of International Organizations $28 \mathrm{I}$ at 286.

7. See Leslie MAASDORP, (20I7) I September “As the BRICS New Development Bank Turns Two, What Has It Achieved?” World Economic Forum.

8. See Mike CALLAGHAN and Paul HUBBARD, "The Asian Infrastructure Investment Bank: Multilateralism on the Silk Road" (2016) 9 China Economic Journal I I 6 at 133. 
the existing order are grounded in banks' constituent documents, important lessons can nevertheless be drawn.

Comparing these two banks will involve a detailed juxtaposition of their constituent documents and bylaws, particularly membership, financing, voting, and governance provisions. This paper will highlight the AIIB's innovations, and will identify positive and negative implications thereof. After describing the process by which incumbent MDBs might implement similar changes, it will assess whether the AIIB has avoided similar constraints. In general, AIIB innovations and deviations from established practice will be emphasized. This paper's primary contribution to existing scholarship is its analysis of the likely impact of these changes on the AIIB's functionality, both within the organization and as one player in the MDB landscape.

As will be seen, in the areas of finance and membership, the AIIB has, on paper, stepped beyond the status quo, while in the realm of voting it has taken a conservative approach. As for governance, the AIIB's structure is itself innovative, although the full impact of this will only become clear as the AIIB finalizes and implements its new lending policies.

\section{MEMBERSHIP}

This section analyses three types of membership provisions: (I) procedural provisions, (2) eligibility provisions, and (3) classes of membership. Regarding the first, the AIIB largely resembles the $\mathrm{ADB}$, at times imitating $\mathrm{ADB}$ Charter language. Both follow standard practice by allowing prospective members to join by depositing an instrument of ratification. ${ }^{9}$ Prior to this, per AIIB Bylaws, prospective members must submit an application. The interim secretariat rejected North Korea's founding member application, indicating that the process is not simply pro forma. ${ }^{\text {IO }}$ Since the Agreement's entry into force, responsibility for passing on such applications lies with the AIIB Board of Directors [BD] and Board of Governors [BG], ${ }^{\text {II }}$ though the exact decision-making method is unclear. Furthermore, while AIIB Bylaws are ambiguous as to whether this procedure applies to states seeking to join by ratification, or only to those seeking to join using the alternative method described below, it has applied to both in practice. ${ }^{\mathrm{I} 2}$ The ADB utilizes a similar approval process, and has thrice rejected North Korea's membership application. ${ }^{\mathrm{I3}}$

9. Asian Infrastructure Investment Bank Articles of Agreement (201 5), art. 58 [AIIB Agreement]; Agreement Establishing the Asian Development Bank, 57I UNTS I23 (I966), art. 64 [ADB Charter] (as amended).

Io. Rahul MISHRA, “Asian Infrastructure Investment Bank: An Assessment” (2016) 72 India Quarterly I 63 at $\mathrm{I} 67$ (citing its "economic as well as political situation [and] abysmal record in dealing with multilateral arrangements"). Diplomatic sources cited North Korea's unwillingness to disclose financial information. "DPRK Refused Entry to China-led AIIB" Global Capital (27 March 201 5 ).

I I. AIIB, "By-laws of the Asian Infrastructure Investment Bank" (20I6), s. 4(a) (applications are submitted to the directors, who may forward them for BG consideration).

I2. See "AIIB Welcomes New Prospective Members", aiib.org (23 March 20I7).

I3. ADB, "By-laws of the Asian Development Bank" (I966), s. I6; Maaike OKANO-HEIJMANS, Economic Diplomacy: Japan and the Balance of National Interests (Leiden: Martinus Nijhoff Publishers, 20I3) at I33. 
Alternatively, both MDBs allow otherwise eligible states to pursue membership under "such terms and conditions as the Bank [AIIB: shall, ADB: may] determine", pursuant to a BG vote-sixty-six percent of members representing seventy-five percent of voting power for the ADB, and a more permissive majority of members representing a majority of voting power for the AIIB. ${ }^{14}$ The banks' withdrawal and suspension conditions are practically identical. Both allow withdrawal at any time on written notice, and both provide for up to one year's suspension, on a Super Majority vote, for failure to fulfil any obligation to the bank. After one year, membership is terminated. ${ }^{{ }^{5}}$

Eligibility provisions are similarly structured, but differ in substance. Regarding state members, MDBs must balance access to additional capital sources ${ }^{16}$ against creditworthiness requirements, since MDBs' credit ratings are influenced by members' sovereign credit ratings, especially where members are few. The AIIB is open to both "members of the IBRD or the ADB" ${ }^{17}$ and applicants who are "not sovereign", but for the conduct of whose international relations an AIIB member is responsible. ${ }^{\text {I }}$ The $\mathrm{ADB}$ is open to "regional countries and non-regional developed countries which are members of the United Nations or of any of its specialized agencies", and "associate members of the UN Economic Commission for Asia and the Far East", ${ }^{19}$ which, where applicable, must have their application presented by the ADB member responsible for their international relations. ${ }^{20}$

Unlike the ADB, AIIB eligibility provisions admit the possibility of a range of nonstate members, though Hong Kong was the only non-state member as of May 2018. Instead of seeking membership, for example, other MDBs have used memorandums of understanding to structure relations with the AIIB. ${ }^{2 \mathrm{I}}$ The European Union [EU] and European Investment Bank [EIB] have, however, reportedly considered applying for AIIB membership. ${ }^{22}$ Controversially, Taiwan's bid for AIIB membership under these provisions was abandoned when Beijing required that Taiwan adopt a Beijingsanctioned name. ${ }^{23}$ Both Taiwan and Hong Kong are full ADB members. ${ }^{24}$ Callaghan

\footnotetext{
14. AIIB Agreement, art. 3(2); ADB Charter, art. 3 (2).

I 5. Compare AIIB Agreement, art. 37; with ADB Charter, art. 4I (withdrawal). Compare AIIB Agreement, art. 38; with $A D B$ Charter, art. 42 (suspension).

I6. See Chris HUMPHREY, “Developmental Revolution or Bretton Woods Revisited?”, Overseas Development Institute Working Paper 4I 8, 2015 , at 3.

I7. Regarding current AIIB members, see Members and Prospective Members of the Bank, aiib.org (last updated 2I May 20I8). The IBRD is not open to non-states, but counts I 89 States Parties, not including North Korea. Articles of Agreement of the International Bank for Reconstruction and Development, 2 UNTS I 34 ( I 945), art. II, s. I(b); Articles of Agreement of the International Monetary Fund, 2 UNTA 40 (I945), art. II, s. 2.

I 8. AIIB Agreement, arts. 3(I)-(3).

I9. These include, e.g. Guam, Hong Kong, Macau, and French Polynesia.

20. ADB Charter, arts. 3(I)-(3).

2I. See e.g. Asian Development Bank, "Memorandum of Understanding for Strengthening Cooperation Between Asian Development Bank and Asian Infrastructure Investment Bank" (2 May 20I6).

22. European Commission, "The Asian Infrastructure Investment Bank", EPSC Strategic Notes I/2015, 2015 , at 4 .

23. See Callaghan and Hubbard, supra note 8 at $\mathrm{I} 29$.

24. Jonathan R. STRAND, Eduardo M. FLORES, and Michael W. TREVATHAN, "China's Leadership in Global Economic Governance and the Creation of the Asian Infrastructure Investment Bank" (20I6) I Rising Powers Quarterly 55 at 59.
} 
and Hubbard have suggested that AIIB provisions allow domestic institutions to join as well. ${ }^{25}$

Regarding classes of membership, the AIIB and ADB share two fundamental similarities and one fundamental difference. First, neither provide for "observer", "associate", or "affiliate" status. At the AIIB, such middle-ground engagement may have attracted the US or Japan. Second, both banks distinguish regional and nonregional members. The "regions" espoused by both banks are essentially equivalent. ${ }^{26}$ Regional members receive special entitlements. For example, regional members are guaranteed seventy-five percent of the AIIB's subscribed capital stock, ${ }^{27}$ and nine out of twelve director seats. ${ }^{28}$ The ADB favours its regional members slightly less, guaranteeing sixty percent of subscribed capital stock, ${ }^{29}$ and eight out of twelve director seats. ${ }^{3 \circ}$ Some argue that this reflects the greater role of non-regional governments in the ADB's founding, ${ }^{3 \mathrm{I}}$ though the absolute number of non-regional founding members was similar for both banks, seventeen for the ADB and twenty for the AIIB. Nonregional members' reduced authority may make some hesitant to join the AIIB, though this has not been the apparent result in practice.

Finally, the AIIB created a class of "founding members", which uniquely receive minor voting privileges. ${ }^{32}$ Typically, a "founding member" designation does not impact a member's rights within an international organization. Overall, by allowing the possibility of non-state members, the AIIB appears slightly more open, and it imposes a lower bar for states unable to join by ratification. The AIIB furthermore elevates regional members' control over decision-making.

\section{FINANCING THE BANK AND FINANCING PROJECTS}

The worldwide infrastructure investment gap in developing countries is estimated to be between \$I and \$2 trillion annually, up to 2030. 33 Though defining "infrastructure" is not straightforward, according to Chiofalo and Miyamoto, China alone represents roughly fifty percent of the infrastructure gap, while other developing Asian countries

\footnotetext{
25. Callaghan and Hubbard, supra note 8 at I29.

26. Ibid. Supra note 5 .

27. AIIB Agreement, arts. 5(2)-(3). A Super Majority can lower this to $70 \%$. Chief Negotiators' Report, supra note 5 at art. $5(2)$; infra note I 40.

28. AIIB Agreement, art. 25(I).

29. $A D B$ Charter, art. 5(I). The Inter-American Development Bank favours regional members even more, leaving a I $5.995 \%$ non-regional voting share. Agreement Establishing the Inter-American Development Bank, 389 UNTS 69 (I959), s. 4(b).

30. $A D B$ Charter, art. 30 (I) (regional members were originally guaranteed 7/Io director seats).

3I. Strand et al., supra note 24 at 64; Callaghan and Hubbard, supra note 8 at I 29.

32. AIIB Agreement, art. $3(\mathrm{I})(\mathrm{b})$.

33. Emilio CHIOFALO and Kaori MIYAMOTO, “Official Development Finance for Infrastructure”, OECD Development Co-operation Working Paper 30, 2016 at 4. Other estimates include: \$776bn annually from 2016 to 2020 , Callaghan and Hubbard, supra note 8, I20; \$60obn annually, plus I0-20\% to mitigate climate change, Griffith-Jones et al., supra note I at 4. But see Reisen, supra note I at 300 (noting the difficulty of estimating infrastructure investment gaps); Mishra, supra note Io at I68 (doubting the number of "investible" projects in Asia).
} 
represent twenty percent. ${ }^{34}$ Assuming that the AIIB focuses on Asian projects outside China, it will thus confront a $\$ 200$ to $\$ 400$ billion annual investment gap. For comparison, infrastructure support from MDBs globally totalled only about $\$ 3$ Ibn in 20I $4 .{ }^{35}$ Pursuant to a 2016 joint declaration by all major MDBs, the ADB made a nonbinding pledge to allocate $\$ 70$ bn to infrastructure between 2016 and 2020, representing seventy percent of its total anticipated lending. ${ }^{36}$ Even with investment from the AIIB, demand for MDB infrastructure loans in Asia is forecast to outpace supply.

MDBs generally possess two types of capital resources—ordinary and special—with the exact contours of each defined in the bank's constituent document. Ordinary resources typically finance non-concessional (market-rate) loans; special resources generally finance concessional (below market-rate) loans. Special resources are typically funded after a bank's creation, pursuant to agreements between the bank and the contributing country. Whereas ordinary resource financing must be profitable in the aggregate, a bank's special resources are often not so limited. Although no bank can sustain itself by consistently losing money, all MDB resources ideally should prioritize development returns over profit. ${ }^{37}$

The ADB's resources have evolved considerably since its I 966 formation. To better reflect recent $\mathrm{ADB}$ innovations, this paper compares the ADB's modern financial resources with those reflected in the AIIB Agreement. It will compare the banks' (I) capital structures (ordinary and special), (2) limits on use and reinvestment, and (3) share allocation provisions.

\section{A. Capital Structures (Ordinary and Special)}

An MDB generally finances non-concessional lending by issuing bonds tied to its ordinary resources on international capital markets. ${ }^{3}$ The higher the bank's credit rating, the better the rate at which it can issue bonds, and thus offer loans to borrowers. With the traditionally closed Chinese bond markets now open, ${ }^{39}$ both banks now have access to basically the same markets. Unlike private financial institutions, MDBs often divide capital between paid-in and callable shares, the latter providing bond purchasers with additional security, but only being called in emergencies. ${ }^{\circ}{ }^{\circ}$ Both the AIIB and

\footnotetext{
34. See Chiofalo and Miyamoto, supra note 33 at 4 .

35. Ibid., at $\mathrm{I}_{3}-\mathrm{I} 443 \%$ of this is concessional and $65 \%$ is non-concessional. At $\$ 5.4$ bn and $59 \%$ of its yearly disbursements, $\mathrm{ADB}$ was the second-largest MDB infrastructure financier).

36. Ibid., at I 8. G20, "MDBs Joint Declaration of Aspirations on Actions to Support Infrastructure" (20I6). The ADB's proportion of lending dedicated to infrastructure exceeds other regional MDBs. Yong Wook LEE, "Institutional Evolution of East Asian Financial Regionalism" (2015) I 3 Korean Journal of International Studies 89 at IOI.

37. Griffith-Jones et al., supra note I at $2 \mathrm{I}$; Li and Wan, supra note 2 at 23.

38. Li and Wan, supra note 2 at 25; Griffith-Jones et al., supra note I at 4; Humphrey, supra note I 6 at 2. See AIIB Agreement, art. 8(ii); ADB Charter, art. 7(ii) (bond financing included among ordinary resources); the AIIB intends to continue this trend. AIIB, "Connecting Asia for the Future: Annual Report and Accounts 20I6" (2016) at 22.

39. David FRANCIS, “China Opens Its Bond Market to International Investors” Foreign Policy (3 July 2OI7).

40. Humphrey, supra note I6 at Io.
} 
ADB expressly provide that members are not liable for bank obligations by virtue of membership. ${ }^{4 \mathrm{I}}$

The AIIB's ordinary capital structure is relatively straightforward. The Agreement authorizes $\$$ Ioobn ${ }^{42}$ in ordinary capital subscriptions, twenty percent paid-in and eighty percent callable. ${ }^{43}$ Most MDBs' callable capital exceeds ninety percent, ${ }^{44}$ so the AIIB's more conservative figure could allow future capital increases without requiring further payments. For now, however, it increases members' financial commitments, and is likely to be another reason why China's proposal to double ordinary capital discouraged non-regional members from pursuing greater voting power during negotiations. ${ }^{45}$ For credit-rating purposes, paid-in capital boosts ratings more than callable capital, the latter being almost entirely discounted under some credit rating agencies' methodologies. ${ }^{46}$ If measuring the practical scale of MDB operations, however, that capital is "callable" is irrelevant. ${ }^{47}$ AIIB governors are empowered to increase ordinary resources through a Super Majority vote, ${ }^{48}$ and must review ordinary resources' adequacy at least once every five years. Upon increasing ordinary resources, each bank member can subscribe in proportion to its pre-increase holdings, under such terms and conditions as the BG shall determine. ${ }^{49}$ The ADB Charter provides for essentially identical reviews once every five years. ${ }^{50}$ These reviews have considerably altered the ADB's capital structure over time.

First, despite an initial authorization of \$Ibn, fifty percent paid-in and fifty percent callable, ${ }^{5 \mathrm{I}}$ only five percent of today's ADB shares are paid-in. ${ }^{52}$ This is the result of five subscription increases, the most expansive of which was a near tripling of the ADB's capital base in 2009, in response to the global financial crisis. ${ }^{53}$ This left the ADB with a \$ 5 3. Ibn capital base. Both the AIIB and ADB limit overall loan portfolios in proportion to total (paid-in and callable) subscribed capital. By default, both provide for a I:I (loans and equity : subscribed capital) lending ratio. ${ }^{54}$ However, the AIIB Agreement empowers the BG to increase this ratio up to 2.5:I via a Super Majority

\footnotetext{
4I. AIIB Agreement, art. 7(3); ADB Charter, art. 5(7).

42. Figures are in US\$.

43. AIIB Agreement, arts. 4(I)-(2). The WB had an 80-20 split in 20I4. Griffith-Jones et al., supra note I at 26. Paid-in shares must be paid to exercise membership rights. AIIB Agreement, art. 6(2). Callable shares are only payable if necessary to meet bank obligations. AIIB Agreement, art. 6(3). In practice, no MDB has ever made a capital call. ADB, "Capital Structure", adb.org (last accessed 28 May 20I 8); Humphrey, supra note 6 at 295.

44. Humphrey, supra note 6 at 289.

45. M. OKOSHI and T. KIKUCHI, "Beijing Holds Sway" Nikkei (23 May 20I 5 ).

46. See Humphrey, supra note 6 at 296-7.

47. Humphrey, supra note i 6 at io.

48. AIIB Agreement, art. 4(3)

49. Ibid., art. 5(4).

50. ADB Charter, art. 5(2).

5I. Ibid., arts. 4(I), 5(I).

52. ADB, "Investor Presentation (2OI 5 )" (May 20I 5), online: ADB < http://www.adb.org/sites/default/files/ page/4I282/adb-investor-presentation.pdf $>$ at 8 .

53. See ADB BG, Resolution 336: Increase in Authorized Capital Stock and Subscriptions Thereto (2009).

54. AIIB Agreement, art. I2(I); ADB Charter, art. I2(I).
} 
vote. ${ }^{55}$ The ADB Charter has no similar provision, but the EIB likewise allows a 2.5:I lending ratio- $\mathrm{a}$ I:I ratio is today seen as "too constraining". ${ }^{56}$

Second, whereas the AIIB Agreement distinguishes ordinary (non-concessional) and special (concessional) resources, the ADB recently deviated from this norm. The AIIB Agreement permits the creation of special funds "designed to serve the purpose and come within the functions of the Bank" ${ }^{57}$ Past practice at other MDBs shows special funds can have a general purpose, or be focused on specific sectors or categories of countries. ${ }^{58}$ The ADB Charter has an equivalent provision, and specifically empowers such funds to be used for concessional lending. ${ }^{59}$ Rather than mentioning concessional lending, the AIIB Agreement instead requires such funds be "on terms and conditions consistent with the purpose and functions of the [AIIB]". This open-ended language, coupled with repeated Chinese statements emphasizing the AIIB's profit-minded nature, may presage an aversion to concessional lending. ${ }^{60}$

Although a large proportion of Asia's infrastructure likely requires concessional finance, ${ }^{6 \mathrm{I}}$ and despite early hope that the AIIB could quickly establish a concessional lending window with lower graduation thresholds than the $\mathrm{ADB},{ }^{62}$ most commentators find "little appetite" for concessional lending at the AIIB. ${ }^{63}$ Though China softened its initial stance, ${ }^{64}$ the Chinese Finance Minister recently described the AIIB as "follow[ing] business lines like private companies", ${ }^{65}$ and stated that the bank "should not have too much of a risk appetite". ${ }^{66}$ This bodes poorly for low-income countries, which often present riskier investments, ${ }^{67}$ but whose need for outside support is most acute. ${ }^{68}$

As of May 20I8, the AIIB had one special fund, the "Project Preparation Special Fund", established with a \$5 om investment from China. The fund finances technical assistance for project preparation, ${ }^{69}$ which is particularly important for less technically experienced countries. ${ }^{70}$ The ADB's “Technical Assistance Special Fund" provides similar support and was established in 1967 , shortly after the ADB's creation. ${ }^{7 \mathrm{I}}$ The

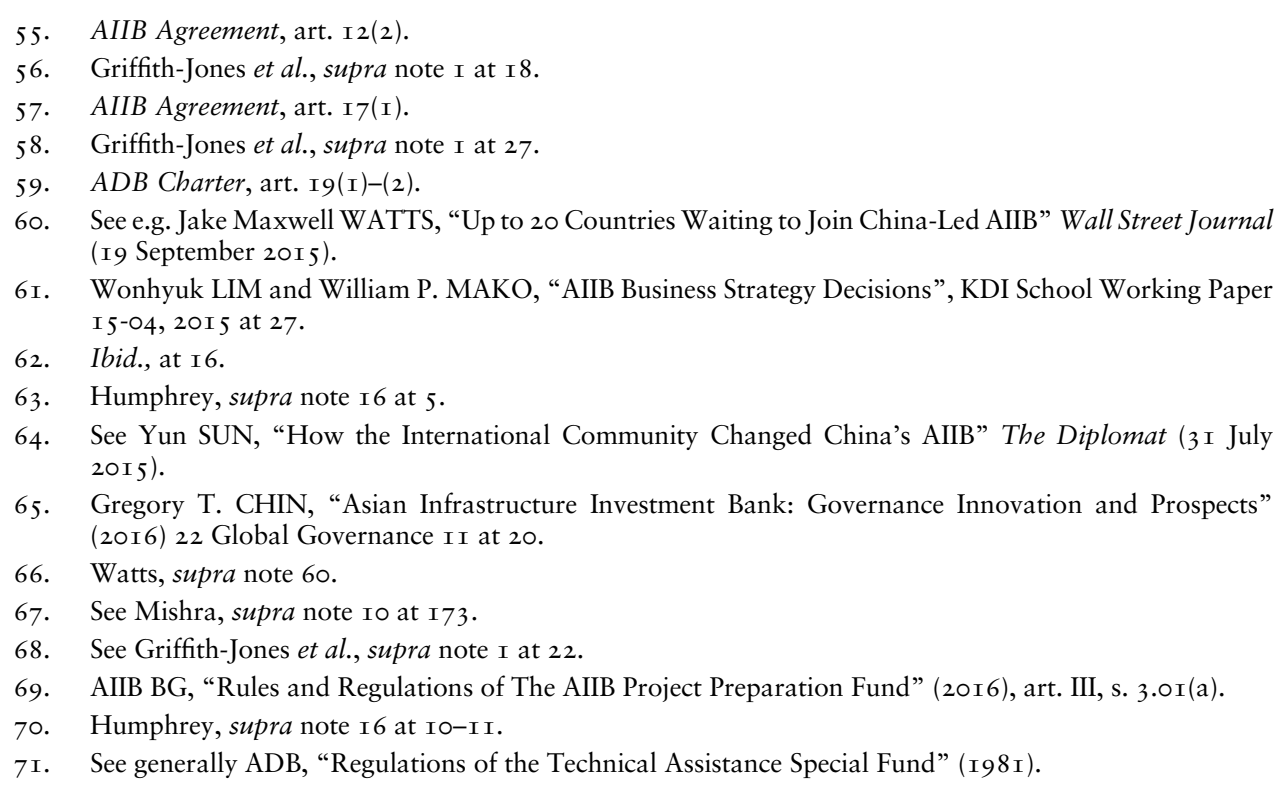


AIIB's fund thus provides little indication of what shape more substantial funds might take.

The ADB's third special fund was established in 1974: the Asian Development Fund. ${ }^{72}$ It existed as a separate, donor-funded concessional lending and grant-making mechanism until 20I7, when ADB BG Resolution $372^{73}$ took the unprecedented step of merging the ADB's ordinary resources with the Asian Development Fund's loan resources. ${ }^{74}$ Hereafter, the Asian Development Fund will only award grants, while its former loan resources will be used to purchase bonds. Officials project a fifty percent increase in the ADB's annual loan and grant approvals by 2020 , with total annual financing reaching roughly $\$ 20 b n .^{75}$ This is because the Asian Development Fund limited lending to immediately available capital; bond financing under the new structure should allow the ADB to lend more.

According to the ADB President, only one of its low-income country borrowers has ever required debt relief; therefore, dedicating Asian Development Fund monies exclusively to concessional lending is inefficient. ${ }^{76}$ Considering this attitude, although the ADB Charter uniquely allows the BG to set aside up to ten percent of unimpaired paid-in capital for a special fund, ${ }^{77}$ it appears unlikely that this provision will see any use soon. The AIIB Charter contains no such provision, and it remains to be seen how the AIIB will approach special funds. Yet, ADB Resolution 372 required the approval of all member countries, meaning China was certainly party to those conversations. ${ }^{78}$ A markedly more favourable approach to concessional lending at the AIIB thus seems unlikely.

Much of the MDBs' financing power is grounded in partnerships. At times, they cofinance with other MDBs. Reisen notes that the AIIB may also partner with BRICS countries' national development banks. ${ }^{79}$ MDBs tend to focus their co-financing efforts on private sources. ${ }^{8 \circ} \mathrm{MDB}$ participation in a project often has a "halo effect" which attracts private investment. ${ }^{8 \mathrm{I}}$ Public-private financing furthermore fosters useful complementarity which can improve project performance. ${ }^{82}$ AIIB officials' statements

72. The second special fund, the Agricultural Special Fund (est. I968), closed in I973. ADB, "ADB Sustainable Development Timeline" (20II), 3. See also Lim and Mako, supra note 6I at I6.

73. ADB BG, "Resolution 372: Enhancing ADB's Financial Capacity for Reducing Poverty in Asia and the Pacific" (2015), s. I (amended by Res. 38I).

74. Asian Development Fund grant resources remain separate. Ibid. No other MDB has done so. ADB, "Frequently Asked Questions: Enhancing ADB's Financial Capacity by Up to $50 \%$ for Reducing Poverty" (3I March 20I5).

75. Takehiko NAKAO, “OP-ED: ADB's New Strategy in Asia” adb.org (Iо January 20I7) (proposal first discussed in 2013).

76. See ibid. Other MDBs suffered significant losses in the Debt Initiative for Heavily Indebted Poor Countries. See Griffith-Jones, supra note I at 22-3.

77. ADB Charter, art. I9(3).

78. See Nakao, supra note 75.

79. Reisen, supra note I at $30 \mathrm{I}$. See also European Commission, supra note 22 at 2 (China's bilateral development banks' joint capital base exceeds \$roobn).

80. Callaghan and Hubbard, supra note 8 at 135 . See also Lim and Mako, supra note 6I at 28 (arguing $5 \%$ $\mathrm{MDB}, 95 \%$ private funding arrangements are possible). But see Chin, supra note 65 at I 8 (private financing is currently at one-third of pre-global financial crisis levels); Griffith-Jones, supra note I at 26 (50-50 financing splits are most common).

8I. Griffith-Jones et al., supra note I at 24.

82. Ibid., at 4 . 
and participation in private financing forums indicate that it intends to be active in this area. ${ }^{83}$ Though MDBs typically handle private financing through a specialized arm, the AIIB's lean staffing policy may preclude this. ${ }^{84}$

\section{B. Limits on Use and Reinvestment}

MDBs most commonly grow their ordinary resources by reinvesting loan payments. ${ }^{85}$ Both AIIB and ADB constituent documents include loan payments among the bank's ordinary resources by default, ${ }^{86}$ though they can be allocated elsewhere through Super Majority $(\mathrm{AIIB})^{87}$ or majority (ADB) votes. ${ }^{88}$ Unlike the $\mathrm{ADB},{ }^{89}$ the AIIB has not yet allocated loan payments to its special fund. ${ }^{90}$ The AIIB's approach is clearly more restrictive. One commentator has argued that having fewer concessional loans may reduce pressure on the AIIB to replenish special funds with interest income, thereby reducing interest rates for non-concessional loans. ${ }^{9 \mathrm{I}}$

MDBs are generally empowered to pursue financing options beyond loans. The AIIB Agreement provides it with a freer hand, notably with regard to equity investments, which it has already pursued. ${ }^{92}$ Equity investments are "inherently riskier" than loans, but may generate greater returns. ${ }^{93} \mathrm{ADB}$ and $\mathrm{AIIB}$ constituent documents thus prescribe limits to balance equity and debt financing.

At maximum, the AIIB may invest roo percent of its capital resources in equity, and another 150 percent in debt. ${ }^{94}$ AIIB operating principles further require that the bank maintain "reasonable diversification" and not assume management responsibilities or a controlling interest "except where necessary to safeguard the Bank's investment". 95 The ADB has a practically identical operating principle, ${ }^{96}$ but empowers the BG to set a strict limit (percent stake) for equity investments. ${ }^{97}$ Furthermore, the ADB's limit on total equity investments is far lower: ten percent of paid-in capital stock, plus bank reserves and surplus. ${ }^{98} \mathrm{With}$ extensive loan profit reinvestment over the years, this is a

83. Chin, supra note 65 at 20 (statements); AIIB, "Multilateral Banks to Deepen Collaboration with Private Sector to Boost Inclusive, Sustainable Infrastructure”, aiib.org (22 April 20I7) (forums). See also AIIB Agreement, art. II(2)(ii).

84. See Chiofalo and Miyamoto, supra note 33 at I7.

85. Griffith-Jones et al., supra note I at 22; Li and Wan, supra note 2 at 24.

86. AIIB Agreement, art. 8(iii). ADB Charter, art. 7(iii). Practice suggests that, like the AIIB, payments on bond- financed ADB loans are included herein. See Li and Wan, supra note 2 at 26.

87. AIIB Agreement, art. I8.

88. ADB Charter, arts. 33(2), 40(3) (Governors must approve net income allocation).

89. See e.g. ADB BG, "Resolution 374: Allocation of Net Income" (4 May 201 5).

90. AIIB, "Project Preparation Special Fund: Auditor's Report for 20I7" (I० April 20I8), I.

9I. See Humphrey, supra note 16 at 5.

92. AIIB, “AIIB Approves its First Equity Investment” (I 5 June 20I7) (\$I $50 \mathrm{~m}$, Indian project).

93. Griffith-Jones et al., supra note I at 23.

94. AIIB Agreement, arts. I2(I)-(2).

95. Ibid., art. I3 (I I).

96. ADB Charter, art. I4(xiii).

97. Ibid., art. I2(4).

98. Ibid., art. I2(3). Li and Wan, supra note 2 at 26 (ADB followed this limitation in practice). 
considerable sum; ${ }^{99}$ but, combined with the requirement that governors approve all equity investments by absolute majority, ${ }^{\text {IoO }}$ it clearly indicates disfavour for equity investments.

Even if the AIIB pursues equity more aggressively, it will likely wait to do so on a large scale. The lifeblood of MDBs remains debt financing on capital markets, and the AIIB will need to gain the trust of those markets to obtain a competitive rate before assuming greater risks. ${ }^{\text {IOI }}$ If the AIIB does pursue extensive equity investment, two of its approaches are likely to come into conflict. Effective equity investing typically requires staff to monitor projects, especially early in the project cycle. ${ }^{\text {IO2 }}$ AIIB representatives have, however, repeatedly pledged to be "lean" with a limited staff. ${ }^{\text {I03 }}$ This should reduce administrative costs, and thereby loan costs. ${ }^{\text {IO4 }}$ But, in notoriously weak governance environments, ${ }^{\text {IO5 }}$ it may impair the bank's ability to effectively monitor projects. Furthermore, as is well recognized, borrowing countries value MDBs' technical expertise, which increases demand for loans. ${ }^{\text {I06 }}$ The AIIB must ensure savings from reduced staffing are not outweighed by reduced development returns due to limited expertise.

\section{Member Share Allocation Provisions}

Finally, the most commented-upon aspect of either bank's financing, aside from overall size, is share allocation provisions, due to voting implications discussed in Section III. At the ADB, governors determine new members' capital stock shares. ${ }^{\text {107 }}$ The AIIB likewise leaves share allocation determinations to the BG, based upon a BD recommendation, ${ }^{\text {I08 }}$ but further requires regional members' shares reflect their share of the global economy, as reflected by their GDP. It is unclear how GDP is to be calculated, whether on a nominal basis (favouring advanced economies) or on a purchasing-power parity basis (favouring developing countries). ${ }^{\text {ro9 }}$ In determining non-regional members' shares, GDP is "only indicative". ${ }^{\text {Iо }}$ This creates more space for negotiation. ${ }^{\text {II }}$ Older international organizations, including the ADB, likewise allow an "informal

\footnotetext{
99. Li and Wan, supra note 2 at 24.

Iо०. ADB Charter, art. II(iii).

IOI. Humphrey, supra note 16 at I6.

I02. Lim and Mako, supra note 6I at i 8 .

I03. Humphrey, supra note 16 at 5.

I04. Ali Burak GÜVEN, “The World Bank and Emerging Powers" (20I7) 22 New Political Economy 496 at 500 .

105. Liu and Pan, supra note 2.

I06. Ibid. (one reason China uses the WB); Humphrey, supra note 16 at 3; ibid. (desirability of development knowledge).

I07. ADB Charter, art. 5(I); ADB By-Laws, supra note $\mathrm{I} 3$ at s. I6.

I08. AIIB Agreement, art. 5(2).

I09. See Manoj KUMAR and Izumi NAKAGAWA, "China's Influence over AIIB a Concern ahead of Founders' Meeting" Reuters (I 3 April 20I 5 ).

I Io. Chief Negotiators' Report, supra note 5 at art. 5(2).

II I. See Strand et al., supra note 24 at 64.
} 
political margin" within which voting shares can be manipulated to achieve a politically desirable distribution. ${ }^{\text {II } 2}$

Furthermore, both banks allow individual members' subscriptions to be increased. The ADB requires (I) a request from the member in question, and (2) terms and conditions which the BG may determine. ${ }^{\text {II } 3}$ The AIIB adds a Super Majority vote requirement, ${ }^{\mathrm{II} 4}$ which, as shown below, cements China's veto over subscription increases.

Finally, paid-in shares must somehow be paid for, either by the Member State or a third-party donor. By default, both banks allow payments in five equal annual instalments, but at the AIIB "less developed countrie[s]" can extend this up to ten instalments. ${ }^{15}$ However, whereas the ADB accepts payments from all countries in the following proportion-fifty percent "convertible currency" and fifty percent member's currency-the AIIB restricts such measures to "less developed countries". ${ }^{\text {I } 6}$ The Chief Negotiators' Report defines this as countries eligible to borrow from the International Development Association, a group which faces chronic USD shortages. ${ }^{\text {II } 7}$

\section{VOTING}

Voting is one of the most discussed aspects of the AIIB's structure, second only to governance provisions. Commentators compare China's position at the AIIB with the US position at the WB and International Monetary Fund [IMF], due to the limited de facto veto power enjoyed by each. ${ }^{I 18}$ Assessing the accuracy of these comparisons is beyond the scope of this paper. As for the AIIB and ADB, while China holds a limited veto at the AIIB, no single state possesses such power at the ADB, though together Japan and the US effectively do.

The banks' general voting structures are similar. ${ }^{\text {II9 }}$ Both allocate votes based on members' capital stock shares, ${ }^{\mathrm{I} 20}$ in addition to "basic shares". "Basic shares" are equal proportions of a set percentage (AIIB: twelve percent, ADB: twenty percent) of "basic shares", "share votes", and at the AIIB, "Founding Member Votes". ${ }^{22}$ Unique among MDBs, the AIIB allocates 600 Founding Member Votes to each country depositing its instrument of ratification by December 2016, a deadline set in

\footnotetext{
I I2. Ibid.

I I3. ADB Charter, art. 5(3). BG Resolutions typically specify the terms and conditions.

I 4. AIIB Agreement, art. 5(3).

I I 5. Compare AIIB Agreement, arts. 6(I), 6(5)(a); with ADB Charter, art.6 (I).

I 16. Compare AIIB Agreement, art. 6(5)(b); with $A D B$ Charter, art. 6(2).

i 7. See Adriana E. ABDENUR, "The New Multilateral Development Banks and the Future of Development" (November 20I 5 ) UN University Centre for Policy Research, 4; Chief Negotiators' Report, supra note 5 at art. 6(5).

I I 8. See e.g. Bob DAVIS and Lingling WEI, "China Forgoes Veto at New Bank to Win Key European Nations' Support" Wall Street Journal (23 March 20I5); Nelson, supra note 4 at I2; Chin, supra note 65 at I3.

I I9. See Strand et al., supra note 24 at 64.

I 20. AIIB Agreement, art. 28(I)(ii); $A D B$ Charter, art. 33(I)(ii).

I2I. Compare AIIB Agreement, art. 28(I)(i); with ADB Charter, art. 33(I)(i). Basic Votes avoid straightforward corporate shareholder-style arrangements, Strand et al., supra note 24 at 63, and boost smaller members' votes, Callaghan and Hubbard, supra note 8 at I 29.
} 
Article 58. ${ }^{\mathrm{I} 22}$ The AIIB's lower percentage of basic shares allows less voting power movement, even if new members were admitted. This was in China's interest as the AIIB's largest shareholder.

As of May 20I 8, China held 300,5 I 8 votes, 297,804 of which are "share votes", for a total of 26.64 percent of AIIB votes. ${ }^{\text {I23 }}$ The AIIB's smallest shareholder, Vanuatu, held 2,II9 votes, 5 of which are "share votes", for a total of 0.I 87 percent of AIIB

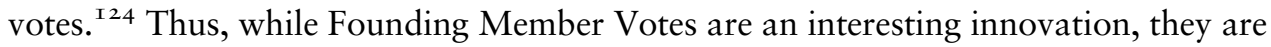
far, far too small to "check" China's influence, contrary to some commentators' assertions. ${ }^{\mathrm{I} 25}$ The ADB's largest shareholders, Japan and the US, each hold I 5.6 percent of ADB shares and I 2.7 percent of ADB votes. The ADB's smallest shareholder, Tuvalu, holds 0.300 percent of ADB votes. ${ }^{\mathrm{I} 26}$ The AIIB provides that states forfeit voting rights for unpaid shares. ${ }^{\mathrm{I}}{ }^{2}$ The ADB has no equivalent provisions, ${ }^{\mathrm{I} 28}$ suggesting late payments are handled through the member suspension process. ${ }^{\mathrm{I} 9}$ The yawning gap in Member States' voting powers, which Humphrey argues left small shareholders at incumbent MDBs with little sense of ownership or commitment, has essentially been reproduced at the AIIB. ${ }^{130}$

The BG is the bank's plenary organ. ${ }^{\text {I3 }}$ Each bank member appoints one governor. ${ }^{132}$ Since MDBs do not operate on a "one nation, one vote" basis, ${ }^{133}$ both banks set dual quorum requirements: (A) two-thirds of voting power, and (B) a majority of governors. ${ }^{\mathrm{I}}{ }^{34}$ By default, the AIIB BG takes decisions by a majority of votes cast, ${ }^{\mathrm{I}} 35$ whereas the ADB requires a majority of voting power represented at the meeting. ${ }^{136}$ As AIIB Rules of Procedure do not require present governors to vote, ${ }^{\mathrm{I} 37}$ certain members could push decisions through despite significant abstentions. Conversely, the ADB standard effectively precludes meaningful abstentions among attending governors. Whereas most Asian and Pacific international organizations have utilized consensus

\footnotetext{
I22. AIIB Agreement, arts. 28(I)(iii), 58. See Strand et al., supra note 24 at 63; Callaghan and Hubbard, supra note 8 at $\mathrm{I} 29$.

I23. India, the second-largest shareholder, holds $8.7 \mathrm{I} \%$ (86,387 votes).

I24. See AIIB, "Members and Prospective Members of the Bank" (I 5 May 20I7).

I 25. See Rebecca LIAO, “Out of the Bretton Woods” Foreign Affairs (27 July 20I 5 ).

I26. ADB, “ADB Annual Report 20I6: Members, Capital Stock, and Voting Power” (2OI7).

I27. AIIB Agreement, art. 6(2).

I28. See supra note II5.

I29. $A D B$ Charter, art. 42; ADB By-Laws, supra note I3 at s. I7.

I30. See Humphrey, supra note 16 at 27.

I3I. Governors can delegate many duties to the non-plenary BD, but not powers "expressly given to" governors by the constituent document. AIIB Agreement, art. 23(2)(xi); ADB Charter, art. 28(2)(xii). Votes described in this section are such specifically assigned powers.

I32. AIIB Agreement, art. 22(I); ADB Charter, art. 27(I). Representatives are usually Secretaries of Treasury, Ministers of Finance, or Central Bank Governors. Nelson, supra note 4 at I2.

I33. Lee, supra note 36 at 93. One exception might be the UN Development Programme; however, it is not traditionally labelled a "bank". See Phillip LIPSCY, "Who's Afraid of the AIIB" Foreign Affairs (7 May 20I 5).

134. AIIB Agreement, art. 24(2); ADB Charter, art. 29(2).

135. AIIB Agreement, art. 28(2)(i).

I36. ADB Charter, art. $33(2)$.

I37. AIIB, "Rules of Procedure of the Board of Governors" (20I6), s. I I.
} 
decision-making since the late $1970 \mathrm{O},{ }^{\mathrm{I}}{ }^{38}$ the ADB predates this, and the AIIB's voting provisions reflect the earlier style, as well as speed considerations particular to MDBs.

Some differences in AIIB and ADB voting requirements have been discussed in Sections I and II. In still other areas, the banks are nearly identical. ${ }^{\mathrm{I} 9}$ The remainder of this section will address additional noteworthy differences. Both banks require that certain decisions be made by "Super Majority", three-quarters of total voting power and two-thirds of governors. ${ }^{\text {I0 }}$ "The AIIB requires certain decisions be taken by "Special Majority", a majority of both total voting power and governors. ${ }^{\mathrm{III}}$ The ADB has a single provision, removal of the President, requiring a vote of two-thirds of total voting power and two-thirds of governors. ${ }^{42}$ For the same task, the AIIB requires a higher Super Majority. ${ }^{143}$ Finally, both banks require unanimity to amend: (i) rights to withdraw membership; (ii) liability limitations; and (iii) rights pertaining to capital stock purchase. ${ }^{\mathrm{I} 44}$ All other amendments can be effected by a Super Majority at either bank. ${ }^{\mathrm{I} 45}$

At the low end, therefore, the AIIB appears more permissive, requiring fewer votes in absolute terms to make decisions. Elsewhere, the AIIB's extensive use of the Super Majority requirement has two effects: (I) for such decisions it grants China, which can prevent a three-quarters majority, a de facto veto; and (2), as discussed below, in some areas it allows a normal vote to accomplish that for which the ADB requires a Charter amendment. This latter observation should temper Callaghan and Hubbard's otherwise correct observation that China's veto power in the AIIB "goes beyond that enjoyed by major shareholders in other MDBs". ${ }^{46}$ Japan and the US maintain a collective veto over Super Majority decisions, including most ADB Charter amendments, and where the Charter itself does not provide for a vote, changes must be effected by amendment—a much more intensive process. Prominent examples of Super Majority modifications permitted by the AIIB, but not mentioned in the ADB Charter, include: (I) adjusting regional members' shareholding ratio; ${ }^{\mathrm{I} 77}$ (2) funding non-member projects; ${ }^{148}(3)$ engaging in financing outside the listed types; ${ }^{\text {I49 }}$ and (4) altering the BD's composition. ${ }^{\mathrm{I} 0}$

\footnotetext{
I38. This is also the trend globally. N. BLOKKER, “Asian and Pacific International Organizations" Grotius Center Working Paper 2016/052-PIL, 23.

I39. Compare, e.g. AIIB Agreement, art. 38(I); with ADB Charter, art. 4I(I) (member suspension); AIIB Agreement, art. 4I; with ADB Charter, art. 45(I) (terminating bank operations); AIIB Agreement, art. 43; with $A D B$ Charter, art. 47(I) (distributing assets upon termination).

I40. The AIIB Agreement coined the "Super Majority" label. AIIB Agreement, art. 28(2)(ii). For the ADB, see e.g. ADB Charter, art. 4(3).

I4I. AIIB Agreement, art. 28(2)(iii). Special Majority votes include: arts. 3(2) (admitting non-IBRD states); 7 (I) (issuing shares other than at par value); II(2)(vi) (financing outside listed types); I6(8) (establishing subsidiary organs).

I42. $A D B$ Charter, art. 34(2).

I43. AIIB Agreement, art. 29(2).

I 44. AIIB Agreement, art. 53(2); ADB Charter, art. 59(2).

I45. AIIB Agreement, art. 53(I); ADB Charter, art. 59(I).

I46. Callaghan and Hubbard, supra note 8 at 130 .

I47. AIIB Agreement, art. 5(2) (though not below $70 \%$ ).

I48. Ibid., art. II(I)(b).

I49. Ibid., art. II(2)(vi).

I 50. Compare AIIB Agreement, art. 25(2); with ADB Charter, art. 30(I)(ii).
} 
Regarding the last of these, the ADB Charter provided only for a one-time review (already completed), whereas the AIIB requires review "from time to time". ${ }^{15}$ The AIIB, however, creates a higher barrier to establishing subsidiary organs, requiring a Special Majority (50.I percent minimum), whereas the ADB requires a majority of voting power represented at the meeting (33 percent minimum). ${ }^{152}$ The Super Majority required to elect the AIIB President grants China significant, if not unlimited, control over the President, which is especially significant considering the AIIB's lack of a resident BD. ${ }^{153}$ The ADB requires a lower Special Majority to elect, ${ }^{\mathrm{I}} 54$ but its President has nevertheless been Japanese since the bank's inception, the result of an informal agreement between the US and Japan. ${ }^{\mathrm{I} 5}$ This custom has proven deeply unpopular among developing countries in the ADB and other MDBs. ${ }^{156}$ A Chinese commentator has raised the possibility of China allowing non-Chinese presidents, ${ }^{157}$ though nonChinese commentators expect Chinese nationals to occupy the AIIB Presidency in perpetuity. ${ }^{\mathrm{I}}{ }^{8}$

In 2015, the Chinese Finance Minister expressed his hope the AIIB would be "mainly led by developing countries". ${ }^{59}$ However, the Agreement presents mixed results. Like the much-criticized voting structure at the IMF (and, less often, incumbent MDBs), ${ }^{160}$ AIIB voting shares remain tied to countries' relative economic weight, though by reflecting current economic power, the AIIB raises certain developing countries' profiles higher than permitted by the ADB's approach. ${ }^{\mathrm{I} 6 \mathrm{I}}$ By securing veto power, Lee argues that the AIIB's decision-making structure "appears to betray [China's] own longstanding stance of constructing nonhegemonic multilateral cooperation". ${ }^{162}$ Thus, whereas China's approach reflects the status quo at most other MDBs, it differs from China's own past practice.

\footnotetext{
I 5 I. See supra note I 50.

I 52. Compare AIIB Agreement, art. I6(8); with ADB Charter, art. 29(4).

I 53. AIIB Agreement, art. 29(I).

I 54. ADB Charter, art. 34(I).

I 55. ADB, "Past ADB Presidents", adb.org (accessed I 5 May 20I7). Henry G. SCHERMERS and Niels M. BLOKKER, International Institutional Law (Leiden: Martinus Nijhoff Publishers, 20I I) at $\$ 352$. Similarly, WB Presidents have always been American and IMF Presidents have always been European. See Rajiv BISWAS, "Reshaping the Financial Architecture for Development Finance", London School of Economics Working Paper 2/2OI 5, 2015 at 4; Callaghan and Hubbard, supra note 8 at I3O. The IMF Presidency was first contested in 2016. Simon CHESTERMAN, "Asia's Ambivalence About International Law \& Institutions” (2016) 27 European Journal of International Law 945.

I 56. Callaghan and Hubbard, supra note 8 at I30.

I 57. Ren XIAO, “China as an Institution-Builder" (2016) 29 The Pacific Review 435 at 439.

I 58. See Daniel C.K. CHOW, "Why China Established the AIIB”, (20I6) 49 Vanderbilt Journal of Transnational Law I 255.

I 59. Enda CURRAN, “China's New Bank Offers Fresh Approach to Old Problems” Bloomberg (26 March 20I5).

I60. See Davis and Wei, supra note iı 8; Rebecca M. NELSON and Martin A. WEISS, "IMF Reforms", Congressional Research Service Report R42844 (9 April 20I 5), 5.

I6I. Annmaree O'KEEFFE, Jonathan PRYKE, and Hannah WURF, “Strengthening the Asian Development Bank in 2 Ist Century Asia”, Lowy Institute for International Policy, February 2017 at I3.

162. Lee, supra note 36 at 99. Lee indicates that China proposed greater control over day-to-day decisions, supra note 36 at Ioo.
} 
Even though China's limited veto does not give it unfettered power to approve decisions, negotiators theorized that with a seventy-five percent regional voting split (a larger stake than warranted by economic weightings alone), ${ }^{163}$ China could "round up" a simple majority with little difficulty. ${ }^{164}$ This alignment likewise makes it unlikely that China will need to rely upon the full weight of its voting share to quash undesired decisions. ${ }^{165}$ Overall, the AIIB's structure reflects China's apparent desire to exercise significant control over its operations; a common (if quixotic) desire among states seeking to multilateralize their activities. ${ }^{166}$ Such a concentration of power belies a democratic deficit in organizational decision-making which limits smaller countries' ability to meaningfully participate in AIIB and ADB leadership.

Some have also observed that China's Super Majority-proof stake is not necessarily guaranteed in perpetuity, as China's voting shares can be diluted as AIIB membership expands. ${ }^{167}$ Negotiators reported that, had Japan and the US joined as founding members, China was willing to forego its Super Majority-proof share. ${ }^{168}$ This did not materialize, but the AIIB Agreement conceivably allows for the later addition of Japan to potentially upset China's narrow veto.

Finally, contrary to concerns expressed during the AIIB's founding, ${ }^{\text {I69 }}$ China's voting share does not give it power to unilaterally direct procurement decisions or project selection. ${ }^{170}$ However, as at the $\mathrm{ADB},{ }^{\mathrm{I} 7 \mathrm{I}}$ China will foreseeably seek to influence such decisions indirectly. ${ }^{\mathrm{I} 2}$ In particular, China's de facto ability to select the President, which leads AIIB management subject to director supervision, is a source of possible concern. ${ }^{173}$ Even assuming full respect for the President's independence while in office, ${ }^{174}$ ex ante domestic screening can nevertheless yield significant de facto control.

\section{GOVERNANCE}

Governance is the most commented-upon aspect of AIIB constituent documents. At one extreme, some argue it is a "foregone conclusion" that China will behave like hegemons in other MDBs, but will wield more far-reaching control. ${ }^{175}$ The Chinese Finance Minister emphasized early that the bank should be "clean". ${ }^{176}$ This section will discuss two

\footnotetext{
I63. Kumar and Nakagawa, supra note ro9.

I64. See Biswas, supra note I 55 at 3; Callaghan and Hubbard, supra note 8 at I I 7 (noting China's larger veto power, compared with existing MDBs).

I65. See Sun, supra note 64.

I66. See Blokker, supra note $\mathrm{I} 38$ at I7.

I67. See e.g. Abdenur, supra note I I7 at 4; Mishra, supra note io at I72-3.

I68. Chin, supra note 65 at I3; Kumar and Nakagawa, supra note Io9.

I69. See e.g. Davis and Wei, supra note i 8.

I70. AIIB Agreement, art. 26(iii)-(iv) (directors' duties).

I7I. See Callaghan and Hubbard, supra note 8 at I3 I.

I72. Abdenur, supra note II7 at 4.

I73. See e.g. Watts, supra note 60.

I74. AIIB Agreement, art. 50.

I75. Chow, supra note 158 at 30.

176. See "AIIB to be lean, clean and green, Chinese officials say" Xinhua (I3 April 2015) ("Lean is cost effective; clean, this bank will have zero-tolerance on corruption; green means it is going to promote the economy").
} 
aspects of MDB governance: (I) the selection, independence, and immunities of bank personnel; and (2) the operating principles and general implementation policies. As seen in the WB's practice, ${ }^{177}$ for example, written standards are necessary but not sufficient for adequate governance. ${ }^{178}$ Much hinges on implementation and organizational culture, both of which remain in the formative stages, although one may reasonably consider China's heavy-handed politicization of Taiwan's application a "warning sign". ${ }^{179}$

\section{A. Selection, Independence, and Immunities of Directors, Officers, and Staff}

Each bank's BG meets infrequently to make major decisions and elect directors and the bank President. ${ }^{\mathrm{I} 80}$ Project-level decision-making is handled by other actors. The ADB, like most incumbent MDBs, has a BD who resides at the bank's headquarters and exercises a regular check on loans, borrowing, and "other bank operations". ${ }^{\text {I8I }}$ By contrast, the AIIB's directors meet only quarterly, ${ }^{182}$ otherwise functioning on a nonresident basis (unless the governors decide otherwise by Super Majority). ${ }^{183}$ Generally, MDBs favour resident BDs for their perceived ability to offer more effective safeguards $;{ }^{\mathrm{I} 84}$ however, resident boards have been criticized for delaying decision-making and increasing overhead costs. ${ }^{185}$ In a resident $\mathrm{BD}$ arrangement, executive officers generally provide managerial services and conduct preliminary investigations before presenting to the directors. ${ }^{\mathrm{I} 86}$ This dynamic often yields potentially disruptive directormanagement tensions. ${ }^{187}$ Thus, while a non-resident board risks reducing safeguards, it also presents opportunities to improve lending efficiency, ${ }^{\mathrm{I} 88}$ and could lessen the bank's ecological footprint by using modern communications technology. ${ }^{\text {I89 }}$

177. Callaghan and Hubbard, supra note 8 at I 34 .

I78. See e.g. ibid., at I35; Strand et al., supra note 24 at 62; Lim and Mako, supra note 6I at 26; Chien-Huei WU, "Global Economic Governance in the Wake of AIIB" (20I7) I 8 Journal of World Investment and Trade 24.

I79. European Commission, supra note 22 at 4.

I80. AIIB Agreement, art. 23; ADB Charter, art. 28 (describing powers). AIIB Agreement, art. 24(I); ADB Charter, art. 29(I) (prescribing annual and "as-required" meetings).

I8I. $A D B$ Charter, arts. 32(I) (resident status), 3 I(ii) (directors' powers), 37(I) (headquarters).

I 82. Chow, supra note I 58 at 23 ("periodically" interpreted as "quarterly"). The EIB's non-resident directors meet ten times per year. Leonardo MARTINEZ-DIAZ, "Boards of Directors in International Organizations" (2009) 4 Review of International Organizations 383 at 398.

183. AIIB Agreement, art. 27(I).

I 84. Callaghan and Hubbard, supra note 8 at I 3 I (EIB is the only other MDB with non-resident directors); World Bank, "Status Report FYo9" (2009), i (WB declined to adopt a non-resident BD); Takatoshi ITO, "The Future of the AIIB", Center on Japanese Economy and Business Working Paper, 20I 5 at 5 (Japan requires a resident BD); Lee, supra note 36 at $\mathrm{IO}_{3}$ (resident BDs are "a minimum condition for institutional autonomy"). But see Humphrey, supra note I 6 at 6 (arguing that resident directors have little development impact).

I 85 . See e.g. Davis and Wei, supra note i I 8; Chin, supra note 65 at I 6 (the Zedillo Commission Report estimates that the IDB BD costs about \$7om annually); Humphrey, supra note I 6 at 20 (percentage of MDBs' net income needed for administrative costs, including directors and staff, ranges from $194 \%$ (IBRD) to $27.5 \%$ (EBRD)). The ADB has one of the lowest administrative expenses to core capital ratios among MDBs. ADB, "Budget of the Asian Development Bank for 20I7" (20I6) at app. 5 s.II.

I86. Lee, supra note 36 at 102 .

I87. Chin, supra note 65 at 16.

I88. See Callaghan and Hubbard, supra note 8 at $\mathrm{I} 3 \mathrm{I}-2$.

I89. Chin, supra note 65 at I7. ADB is likewise pursuing such efficiencies. ADB, "ADB Environmental Operational Directions 2013-2020" (2013), I4. 
The AIIB President, Vice-Presidents, and staff handle day-to-day decision-making. ${ }^{\text {I90 }}$ Humphrey alleges that the AIIB's Draft Finance Policy unprecedentedly allows the President to directly approve loans under \$30om (public sector) and \$200m (private sector), subject to BD guidelines, ${ }^{191}$ but this has not yet taken effect, as all financing is currently subject to BD approval. ${ }^{192}$ Selection processes can help predict principal-agent problems between Member States and bank employees. The governors elect (and can dismiss) the AIIB President for a five-year term by Super Majority vote. ${ }^{193}$ Whereas large international organizations rarely provide for dismissal, so as to safeguard the secretariat's independence, multilateral financial institutions are an exception to this rule. ${ }^{194}$ The AIIB's removal provision is nonetheless noteworthy for setting a higher threshold than the ADB, which requires two-thirds of votes and two-thirds of members. ${ }^{195}$ This reduces the AIIB President's independence, however, as the same single member can veto both election and removal.

Predictably, the AIIB's first President was Jin Liqun, the Chinese official selected by Beijing to spearhead the AIIB formation process. ${ }^{196}$ Vice-Presidents are "appointed [for a term] by the [BD] on the recommendation of the President, on the basis of an open, transparent and merit-based process", ${ }^{197}$ whereas other staff are appointed and dismissed by the President, in accordance with BD regulations. ${ }^{\text {I98 }}$ Importantly, the AIIB Agreement repeats the ADB Charter's universal recruitment languagemeaning neither bank must select officers or staff from Member States, aside from the President, who must be a national of a regional member. ${ }^{199}$ Making English the AIIB and ADB's working language helps actualize international recruitment. ${ }^{200}$ In fact, several Americans, including former WB employees, have been hired as AIIB consultants. $^{20 \mathrm{I}}$

AIIB governors elect directors for renewable two-year terms. Whereas the ADB pays directors a salary, providing a veneer of independence to suggest that they are beholden to the institution rather than electing states, ${ }^{202}$ the AIIB has eliminated remuneration provisions. ${ }^{203}$ With AIIB directors furthermore not resident at AIIB headquarters, they appear less like institutional representatives and more like state surrogates. It is a legal fiction to expect paper privileges and immunities alone to secure directors' de facto

\footnotetext{
I90. AIIB Agreement, art. 32 (I).

I9I. Humphrey, supra note 16 at 6.

I92. AIIB, "Operational Policy on Financing" (last updated 2I March 20I7), s. 3.5.I ftn. I6.

193. AIIB Agreement, art. 29(I)-(2).

I94. Blokker, supra note I 38 at 30.

195. $A D B$ Charter, art. 34(2).

I96. AIIB, “AIIB Open for Business" (I6 January 20I6); Chin, supra note 65 at I4.

197. AIIB Agreement, art. 30(I). AIIB By-Laws, supra note I I at Sec.I 2.

198. AIIB Agreement, art. $30(2)$.

I99. Compare AIIB Agreement, art. 30(3); with ADB Charter, art. 34(6) (universal recruitment). Compare AIIB Agreement, art. 29(I); with ADB Charter, art. 34(I) (President's nationality).

200. AIIB Agreement, art. 34(I); ADB Charter, art. 39(I).

20I. See e.g. Davis and Wei, supra note i 8.

202. Ana Sofi BARROS, “Governance as Responsibility”, University of Leuven, Belgium, PhD thesis, (20I7) at 242-3.

203. AIIB Agreement, art. 25(5)-(6).
} 
international civil servant status. ${ }^{204}$ This may have been a deliberate compromise to facilitate greater state control over the persons tasked with overseeing AIIB personnel. Removing remuneration primarily benefits members with large voting shares and thus sizeable "stakes" in a director. Failing to adequately insulate directors from members' political aims may threaten efficiency gains from non-resident arrangements.

Regional (nine) and non-regional (three) directors are elected separately. Each state can nominate one candidate, and vote for one candidate. ${ }^{205}$ Top vote-getters to receive at least six percent of regional members' votes or fifteen percent of non-regional members' votes are elected. ${ }^{206} \mathrm{~A}$ run-off may be held if voting thresholds are not met on the first ballot. ${ }^{207}$ Members are not required to vote. ${ }^{208}$ In theory, abstention would allow China to forego electing a director, enabling the formation of a more balanced BD to exercise oversight over a staff likely headed by a Chinese President. Although directors owe a dual responsibility on paper-to both the state(s) they represent and the organization as a whole-in practice their state-representative role, especially for single-country directors, is so predominant that the duality issue "should not even be raised". 209

The ADB President and Vice-President are selected in the same manner as at the AIIB, except the President is elected by Special Majority. ${ }^{2 \text { Io }}$ ADB directors also serve renewable two-year terms. ${ }^{2 \mathrm{II}}$ The process is essentially similar to that of the AIIB, except required vote thresholds are raised to eight percent of regional members' votes (for eight directors) and seventeen percent of non-regional members' votes (for four directors). ${ }^{2 \mathrm{I} 2}$ States are required to vote. ${ }^{213}$ The AIIB's lower voting thresholds grant slightly more power to smaller shareholders.

The AIIB Agreement does not specify the number and regional/non-regional make-up of Vice-Presidents, but its first group included five members hailing from Germany, the UK, France, India, and Indonesia. ${ }^{2 \mathrm{I}} 4$ Unlike the ADB Charter, the AIIB Agreement expressly requires both Presidents' and Vice-Presidents' selection processes to be "open, transparent and merit-based". ${ }^{25}$ Nevertheless, emphasis on procedural transparency allows substantive obscurities. For example, President Jin's precise position within the Chinese Communist Party might impact members' assessment of his independence, but is undisclosed. ${ }^{216}$ This is ostensibly treated by requiring AIIB personnel to tender offers of

\footnotetext{
204. See Barros, supra note 202 at 244-6.

205. AIIB Agreement, sch. B, arts. 5-6.

206. Smaller shareholders typically form coalitions to elect directors. Coalition decision-making generally reflects individual members' relative quotas. Barros, supra note 202 at 233-4.

207. AIIB Agreement, sch. B, arts. 3, 7-8.

208. Ibid., art. 9 .

209. See Barros, supra note 202 at $234-5$.

2 го. ADB Charter, art. 34(I)-(2) (President); 35 (Vice Presidents). ADB By-Laws, supra note I3 at s. 6 (employment terms).

2II. ADB Charter, art. $30(3)$.

2I 2. Ibid., annex B, s. A, art. 2 (regional, BG Resolution 27 lowered from Io\%) and s. B, art. 2 (non- regional, BG Resolution 37 lowered from $25 \%$ ).

213. Ibid., annex B, s. A, art. I (regional) and s. B, art. I (non-regional).

2I4. AIIB Annual Report, supra note 38 at I I.

21 5. AIIB Agreement, arts. 29(I) (President), 30(I) (Vice-Presidents).

216. See Chow, supra note 158 at 23.
} 
resignation if "appointed to a political office" during their tenure, ${ }^{217}$ though beyond officers' duty to self-report, the AIIB's ability to enforce this provision is unclear. ${ }^{218}$

Finally, AIIB and ADB Presidents can appoint and dismiss other staff, in accordance with $\mathrm{BD}$ regulations. ${ }^{219}$ AIIB regulations require competitive appointment, "so far as is practicable" on "as wide a regional geographic basis as possible", "subject to the paramount importance of securing the highest standards of efficiency and technical competence". ${ }^{20}$ Uniquely, initial appointments at the AIIB may be for only three years, ${ }^{22}$ a limit which constrains staff independence. As for termination, the President may unilaterally terminate personnel for "unsatisfactory" services, but must provide reasons in writing. ${ }^{222}$ The AIIB's administrative dispute resolution system has not yet been established, leaving it unclear whether the President's decision is subject to any meaningful employee challenge. ${ }^{23}$ It is assumed that a Chinese AIIB President would avoid the practice, common to central government appointments, of stocking senior positions with handpicked party favourites; ${ }^{24}$ however, the vague regulations leave room for concern.

To counter this temptation, independence rules, privileges, and immunities help to safeguard MDBs' organizational independence. ${ }^{225}$ These reduce outside interference in bank operations, and help to safeguard members' investment in a multilateral structure, the ability of which to add credibility and reduce politicization depends upon being perceived as independent. ${ }^{226}$ Both banks' independence provisions resemble UN Charter Article Ioo, generally considered the standard in this area, ${ }^{27}$ providing that bank officers and staff owe a duty only to the bank and prohibiting members from seeking to influence employees' activities. ${ }^{228}$

Textually, each bank's employee privileges and immunities provisions are nearly identical. ${ }^{229}$ Both apply to all governors, directors, officers, and employees. The AIIB expressly includes its Presidents and Vice-Presidents. While both create immunity from legal process for acts performed "in their official capacity", subject to waiver by the bank, the AIIB expressly extends this to an inviolability of official papers. ${ }^{230}$ AIIB

217. AIIB, "Code of Conduct for Bank Personnel" (January 2016) at s. 22. The rule applicable to bank directors differs materially.

218. Ibid., at s. 38 .

219. $A D B$ Charter, art. 34(5). "Staff Regulations of the Asian Infrastructure Investment Bank" (20I6).

220. AIIB Agreement, at art. 5(I)-(2) (emphasis added).

22 I. AIIB Annual Report, supra note 38 at Iо; "Staff Regulations of the AIIB" (20I6), arts. 6-7(I); ADB, "Professional Staff Information Guide" (20IO), II (thereafter allowing extension or conversion to "regular status").

222. AIIB Agreement, at art. 7(3)(ii).

223. Ibid., at art. I3. The second round of public consultations concluded on $26 \mathrm{March} 20 \mathrm{I} 8$, but a final draft of the complaints handling mechanism has not yet been issued. AIIB, "Complaints Handling Mechanism" (28 May 20I 8).

224. See Chow, supra note 158 at 24.

225. See e.g. Blokker, supra note $\mathrm{I} 38$ at $24,27$.

226. See Callaghan and Hubbard, supra note 8 at I22-3.

227. Blokker, supra note 138 at 27.

228. Compare AIIB Agreement, art. 3I(3); with ADB Charter, art. 36(3); with 1945 Charter of the United Nations, I UNTS I 6 (I945), art. Ioo.

229. Compare AIIB Agreement, art. 50; with ADB Charter, art. 55. 
privileges related to travel and immunities are standard for MDBs and are copied verbatim from the ADB Charter. So, at least on paper, AIIB personnel are afforded slightly more expansive immunities than their ADB counterparts. Considering the significant corruption problems in China and other borrowing countries, ${ }^{2{ }^{2} \mathrm{I}}$ it is important that the bank operationalize this safeguard.

\section{B. Operating Principles and General Implementation Policies}

Theoretically, an MDB employee, competitively selected and empowered to independently act, but subject to weak operating principles, could comply with the bank's constituent document yet fall short of widely accepted standards. Operating principles broadly laid out in each bank's constituent document are supplemented by more detailed policies, e.g. environmental and social standards, enacted by the directors. The AIIB's operating principles appear largely based on those of the ADB. ${ }^{232}$ Where the two diverge, AIIB principles generally improve upon ADB principles.

First, the commonalities-both banks pledge to: preclude projects in a member's territory if that member objects; ${ }^{233}$ principally finance specific projects, not slush funds ${ }^{234}$ consider prospective borrowers' ability to obtain alternative financing and repay; ${ }^{235}$ devise "appropriate" interest and payment schedules for each loan; ${ }^{236}$ reasonably diversify equity holdings; only seek controlling stakes necessary to protect the bank's investment; ${ }^{237}$ and avoid disproportionately financing one member. ${ }^{23^{8}}$ This final provision is particularly relevant at the AIIB, to the extent that China secures a Chinese President while remaining eligible for AIIB loans. ${ }^{239}$ Both banks also pledge to ensure that [AIIB: "financing", ADB: "loan"] proceeds are not used for unintended purposes. ${ }^{24}$ Furthermore, both banks pledge to observe "sound banking principles", though this is the AIIB's first operating principle, and the ADB's last, which reflects China's business-focused membership pitches. $^{24 \mathrm{I}}$

One of the AIIB's more noteworthy improvements is in not restricting procurement to Member States. ${ }^{242}$ President Jin specifically stated that Chinese companies would not be favoured, ${ }^{243}$ a break from Chinese officials' earlier statements casting the bank

\footnotetext{
230. AIIB Agreement, art. 50(i).

23I. See Biswas, supra note 155 at 9 (citing Transparency International's Corruption Perceptions Index).

232. Strand et al., supra note 24 at 62.

233. By using "member", rather than "Member State", the AIIB allows entities such as Taiwan to exercise control, if admitted. Compare AIIB Agreement, art. I3(3); with ADB Charter, art. I4(iii).

234. Compare AIIB Agreement, art. I3(2); with $A D B$ Charter, art. I4(i).

235. Compare AIIB Agreement, art. I3 (5)-(6); with ADB Charter, art. I4(v)-(vi).

236. Compare AIIB Agreement, art. I3 (7); with $A D B$ Charter, art. I4(vii).

237. Compare AIIB Agreement, art. I3(I I); with $A D B$ Charter, art. I4(xiii).

238. Compare AIIB Agreement, art. I3(Iо); with ADB Charter, art. I4(xii).

239. See Ito, supra note I 84 at 4 . Japan is ineligible for ADB loans.

240. Compare AIIB Agreement, art. I3(9); with ADB Charter, art. I4(xi).

24I. Compare AIIB Agreement, art. I3(I); with ADB Charter, art. I4(xiv). See AIIB Agreement, art. 9(I).

242. Compare AIIB Agreement, art. I3 (8); with $A D B$ Charter, art. I4(iix) (directors, by a two-thirds vote, can extend procurement to non-members).
} 
as an outlet for China's overcapacity. ${ }^{244}$ Where local content requirements support home-grown technological development, however, fully open procurement could actually inhibit development returns. ${ }^{245}$ Accordingly, the AIIB's procurement policy provides exceptions for domestic industry development. ${ }^{246}$

Additionally, the AIIB expressly requires that operations comply with its economic and social policies, whereas the ADB simply refers to its purpose to prioritize "harmonious [regional] economic growth", with special regard to less-developed members' needs. ${ }^{247}$ Elsewhere, however, the AIIB states: "Only economic considerations shall be relevant to [...] decisions [by AIIB officers and staff]." It is unclear how these two provisions might interact. ${ }^{248}$ Furthermore, the Agreement does not indicate whether "social standards" include human and workers' rights, prompting doubts from one commentator. ${ }^{249}$ As of August 20I7, however, the AIIB had used other MDBs' standards for all co-financed and most self-financed projects. ${ }^{25}$ Though its Oman projects use AIIB standards and make no mention of human and workers' rights in the evaluation, ${ }^{25}$ both rights are referenced in the AIIB's Environmental and Social Framework. ${ }^{252}$

Eliminating the ADB requirement that loans be disbursed as expenses are incurred, ${ }^{253}$ depending on how it is implemented, could improve project efficiency and reduce delays, though it could facilitate corruption if inexpertly overseen. Ideally, the "sound banking principles" requirement should entail sufficient safeguards. Likewise, "sound banking principles" probably encompass the omitted ADB operating principle mandating "suitable" compensation for underwriting risks. ${ }^{254}$ Finally, the AIIB eliminates the requirement that applicants submit loan proposals to the bank President for presentation to the directors. ${ }^{255}$ Non-resident directors make such rigid procedural

243. Watts, supra note 60.

244. See Sun, supra note 64; Wang, supra note 2. This dampens predictions that the AIIB will funnel work to Chinese state-owned enterprises. Chow, supra note 158 at 27.

245. Griffith-Jones et al., supra note I at I9.

246. AIIB, "Procurement Policy" (20I6), s. 5.7.

247. Compare AIIB Agreement, art. I3(4); with ADB Charter, art. I4(ii). The AIIB Agreement reproduces these purposes. AIIB Agreement, art. 2(ii). See also Laura HENRY, "Ensuring Accountability for Environmental and Social Policies in the AIIB" (2015) I 8 Korea University Law Review 37 at 55; Wu, supra note $\mathrm{I} 78$ at 24 .

248. AIIB Agreement, art. 3 I(2).

249. Chow, supra note 158 at 25.

250. See e.g. AIIB, "Project Document of the AIIB: India: Andhra Pradesh 24X7 Power for All Project" (I4 April 20I7), 24 (co-financed); AIIB, "Project Document of the AIIB: Bangladesh: Natural Gas Infrastructure and Efficiency Improvement Project" (27 March 20I7), para. 54 (self-financed, ADB standards).

25I. AIIB, "Project Document of the AIIB: Oman: Duqm Port Commercial Terminal and Operational Zone Development Project" (8 December 2016) at paras. 46-7.

252. AIIB, "AIIB Environmental and Social Framework" (20I6), para. 8 (human rights, general reference), I 5 (labour rights, more specific) $[A I I B-E S F]$. See also A. KÄMPF, "New Environmental and Social Standards at the Wolrd Bank [sic] and the AIIB", Deutsches Institut für Menschenrechte Position Nr. 4 (20I6) (translation), 2 (evaluating AIIB labour standards).

253. ADB Charter, art. $\mathrm{I} 4(\mathrm{x})$.

254. Ibid., art. I4(viii).

255. Ibid., art. I4(iv). 
requirements superfluous, though financing applications continue to feature similar documents, e.g. impact assessments. ${ }^{256}$

The ADB and AIIB prohibit political considerations from influencing bank personnel and interference in domestic politics. ${ }^{257}$ However, market- and ideology-driven opposition to loan conditionality may lead the AIIB to reinterpret this broad language. Recently, non-concessional MDB loan recipients have favoured more expensive, less conditional borrowing options. ${ }^{258}$ The Chief Negotiators' Report prohibits the AIIB from taking a stance on existing territorial disputes. ${ }^{259}$ While the AIIB's other operational standards are generally compatible with those of existing MDBs on paper, ${ }^{260}$ operationalization may present hazards for smooth inter-MDB co-operation. Furthermore, if political "interference" is interpreted too broadly, this could impair development returns, as twenty percent of incumbent MDBs' “infrastructure" assistance targets policy frameworks and non-physical aspects of the investment environment, ${ }^{261}$ which can otherwise undermine physical projects. ${ }^{262}$

Specific economic, social, and other policies are not specified in either bank's constituent document. At the AIIB, such policies require BD approval and "should be based on international best practices". ${ }^{263}$ This language suggests closer status quo adherence than earlier, more measured Chinese statements. ${ }^{264}$ Nevertheless, director approval necessitates near-unanimous support from states in a region which generally holds traditional notions of state sovereignty and is hostile towards conditionality. ${ }^{265}$ While many AIIB operational standards are still pending, those proposed underwent two rounds of public comment prior to voting and adoption. ${ }^{266}$ In February 2016, the AIIB adopted its Environmental and Social Framework [ESF]. Although all bank policies can impact bank functioning, ${ }^{267}$ this section will assess only the ESF.

Borrowers have criticized detailed ESFs at incumbent MDBs as slow, excessively bureaucratic, expensive, and intrusive. ${ }^{268}$ Lenders generally drive ESFs and loan conditions, ${ }^{269}$ and NGOs responsible for ESF lobbying complain that existing frameworks do not go far enough. ${ }^{270}$ Lim and Mako opine that this two-sided criticism indicates

\footnotetext{
256. AIIB-ESF, supra note 252 at paras. 69-70.

257. AIIB Agreement, art. 3 I(2); ADB Charter, art. 36(2).

258. Humphrey, supra note 16 at 2.

259. Chief Negotiators' Report, supra note 5 at art. I3(4).

260. Cf. Amitav ACHARYA, “AAlternative' Regional Institutions in Asia?” (2015) 2 Georgetown Journal of Asian Affairs: Policy Forum 4.

26I. See Chiofalo and Miyamoto, supra note 33 at I6 (reproducing 20I4 figures).

262. Callaghan and Hubbard, supra note 8 at I24.

263. Chief Negotiators' Report, supra note 5 at art. I3(4).

264. Ito, supra note 184 at 5 .

265. See Henry, supra note 247 at 55 .

266. See e.g. AIIB, “AIIB Launches Final Round of Consultation on Draft Energy Strategy”, aiib.org, 24 January 2017.

267. See e.g. AIIB Agreement, art. 34 (transparency policy); Henry, supra note 247 at 55 .

268. Callaghan and Hubbard, supra note 8 at I33-6; Humphrey, supra note 16 at Io. See also Reisen, supra note $\mathrm{I}$ at 302 (on average, ADB projects require seven years from proposal to completion).

269. Humphrey, supra note 16 at 26.

270. Lim and Mako, supra note 6I at 25.
} 
that MDBs have struck the right balance, ${ }^{27 \mathrm{I}}$ whereas Humphrey argues that it reflects a counter-productive "us versus them" mentality between the two camps. ${ }^{272}$ Regardless, both camps continue to seek to improve existing ESFs.

MDBs have gradually enhanced ESFs based upon decades of experience, ${ }^{273}$ much of which was infrastructure-focused at the ADB. ${ }^{274}$ Chin describes this as setting the standard that the AIIB "must either meet or try to exceed", ${ }^{275}$ yet that standard is not static. For example, ADB reforms have gradually increased reliance on borrowers' domestic monitoring systems. ${ }^{276}$ This flux makes incorporating MDBs' "lessonslearned" no straightforward exercise. Bilateral development banks of major ADB shareholders, Japan and the US, likewise have considerable ESF experience. ${ }^{277}$ China lacks extensive experience with ESFs in bilateral projects, ${ }^{278}$ despite considerable investment in domestic and African infrastructure. ${ }^{279}$ This gap leaves China less able to leverage its experience for evidence-based improvement of incumbent ESF regimes. ${ }^{280}$

Cognizant that incumbent ESFs arguably represent "broadly accepted global norms", ${ }^{28 \mathrm{I}}$ the AIIB employed former WB staff in developing its frameworks. ${ }^{282}$ Perhaps as a result, drafts "seem[ed] to say all the right things", though details were not finalized. ${ }^{283}$ Furthermore, drafting encountered several delays, which some read as indicating the AIIB's seriousness, and others read as reflecting the difficulty of reaching consensus. ${ }^{284}$ The latter explanation would hardly be surprising, as efforts to streamline ESF procedures could potentially undermine AIIB promoters' pledges to create a "clean" institution. Furthermore, maximizing speed does not always maximize development results, ${ }^{285}$ and risky projects might not permit pared-down ex ante screening. ${ }^{286}$ Yet, by placing more power in borrowing countries' hands to draft or approve ESFs, one would expect changes responsive to their complaints about incumbent standards. ${ }^{287}$ Due to space constraints, this section will compare only environmental safeguards-the ADB's 2009 Safeguard Policy Statement, as interpreted by the Environmental Operational Directions 2013-2020, with the AIIB's 2016 Environmental and Social Framework [AIIB-ESF].

27I. Ibid.

272. Humphrey, supra note 16 at 27.

273. Chin, supra note 65 at 21 .

274. Callaghan and Hubbard, supra note 8 at I33.

275. Chin, supra note 65 at 21 .

276. Griffith-Jones et al., supra note I at 20.

277. Henry, supra note 247 at $4 \mathrm{I}-2$.

278. Callaghan and Hubbard, supra note 8 at I 33 (bilateral development institutions); Chow, supra note I 58 at 26 (bilateral trade agreements).

279. Chiofalo and Miyamoto, supra note 33 at 6.

280. See Griffith-Jones et al., supra note I at $3 \mathrm{I}$; Wu, supra note $\mathrm{I} 78$ at 23.

28I. Chin, supra note 65 at $2 \mathrm{I}$.

282. Ibid., at I4-I5.

283. Humphrey, supra note 16 at 6.

284. Chin, supra note 65 at 21 .

285. Griffith-Jones et al., supra note I at I9-20.

286. Ibid., at 20. The WB's "programme for results" takes this approach. Lim and Mako, supra note 6I at 24.

287. See Lim and Mako, supra note 6I at 26. 
Both environmental procedures are similarly structured, ${ }^{288}$ though the AIIB appears poised to reduce ex-ante assessment and emphasize implementation monitoring. Aside from some smaller differences, ${ }^{289}$ the AIIB's most significant change is its stance towards country systems. Use of domestic safeguard mechanisms in lieu of MDBs' is something middle-income countries have sought since at least the early 2000 s to reduce lending transaction costs. ${ }^{290}$ However, while incumbent MDBs have piloted such programmes, requiring near equivalence with MDB safeguards has severely limited their use. ${ }^{29 I}$ The ADB currently seeks to "strengthen and clarify" the role of local personnel, by developing local capacity "to match international best practice". ${ }^{292}$ ADB efforts are not just bilateral-it has spearheaded regional initiatives including the Asian Environmental Compliance and Enforcement Network, and Asian Judges Network on the Environment. ${ }^{293}$ Thus, the effort extends far beyond the capacity-building possible through a project preparation special fund. ${ }^{294}$ Whereas such capacity-building is a cornerstone of the ADB's development concept, similar statements in AIIB documents omit capacity-building, ${ }^{295}$ arguing instead that the best way to strengthen domestic mechanisms is to use them. ${ }^{296}$

Thus, while the ADB's most recent policy directions eschew a "one size fits all" approach to safeguards, ${ }^{297}$ its Safeguard Policy Statement nevertheless favours capacity-building to improve domestic standards, rather than loosening ADB environmental standards. ${ }^{298}$ The AIIB's approach appears to better integrate country systems, something recommended in 2006 by the ADB's evaluation department (though it also recommended increased capacity-building). ${ }^{299}$ The AIIB-ESF states it "may selectively" allow borrowers to use their own systems in place of part or all of the AIIBESF on a project, sectoral, or other level, the borrower must substantiate (I) its ability and capacity to (2) achieve objectives materially consistent with the AIIB-ESF. ${ }^{300}$ This may lead to a significant shift towards country systems, which could allow more efficient application of safeguard standards. To ease other MDBs' fears about working at cross-purposes, the AIIB-ESF further states that it will "coordinate closely" with other

288. Compare e.g. ADB, "Safeguard Policy Statement" (2009), para. 59 [ADB-S.P.S.]; with AIIB-ESF, supra note 252 at para. 62 (implementation monitoring). But see Chow, supra note 158 at 25 (Indonesian statement that AIIB imposes looser environmental requirements).

289. Compare e.g. ADB-S.P.S., supra note 288 at paras. $65-7$; with AIIB-ESF, supra note 252 at para. I3 (similar project categories and obligations for intermediaries, but AIIB does not mention due diligence review).

290. ADB-S.P.S., supra note 288 at para. 37.

29I. See e.g. Juan D. QUINTERO, Alberto NINIO, and Paula J. POSAS, "Use of Country Systems for Environmental Safeguards", The World Bank Group, 22 February 20 I I at 3.

292. Environmental Operation, supra note I 89 at Io.

293. Ibid.

294. See supra notes 69-70.

295. Compare ADB-S.P.S., supra note 288 at para. 7I; with AIIB-ESF, supra note 252 at para. IO.

296. AIIB-ESF, supra note 252 at para. I2.

297. Environmental Operation, supra note I 89 at I7. See ADB-S.P.S., supra note 288 at para. 4I (legalistic safeguard implementation increases transaction costs).

298. ADB-S.P.S., supra note 288 at para. 37.

299. Ibid., at para. 20; Humphrey, supra note $\mathrm{I} 6$ at 6 (praising integration of country systems).

300. AIIB-ESF, supra note 252 at paras. 52-6. 
MDBs in applying these standards. ${ }^{301}$ Nevertheless, commentators have criticized AIIB standards for lacking binding criteria to ensure comparable protection, and questions persist over the eventual oversight mechanism. ${ }^{302}$ Despite similarities on paper, commentators are rightly wary of drawing conclusions until implementation can be observed. ${ }^{303}$

\section{EXISTING MDBS’ATTEMPTS TO UPDATE}

Despite tectonic shifts in the world economy since $1944,{ }^{304}$ in many respects MDBs are perceived as having "hardly evolved" or having done so "painfully slow[ly]".305 Testing the accuracy of this perception is beyond the scope of this paper, but institutional factors frustrating such updates bear mentioning, as inflexibility yields new initiatives. $^{306}$ The AIIB was, of course, one such initiative, but as an MDB it will hereafter face similar constraints in updating its constituent document. As perhaps the most hotly debated reform, this section discusses rebalancing countries' "voice" in existing MDBs.

If "voice" in an institution is defined broadly, MDBs may flexibly adjust this at the executive level, e.g. by increasing consultation with borrowing-country stakeholders, hiring more borrowing-country officers, limiting the number of countries each board member can represent, ${ }^{307}$ or adapting managerial policies to borrowing-country concerns. ${ }^{308}$ However, such adjustments have not placated countries in the past, and the lack of uniform member support frustrates more fundamental reforms. China can effectively veto any amendment to the AIIB Agreement. ${ }^{309}$ In other institutions with a veto-wielding member, such as the IMF/WB (US), domestic inertia can delay changes requiring veto-proof votes. ${ }^{3 \text { ro }}$

However, MDB reforms can be implemented in various ways; the WB considered at least thirteen options for increasing developing countries' voice. ${ }^{3 \text { II }}$ One faces a particularly high barrier: amending the "preemptive rights principle", which guarantees members a share of new subscriptions proportional to pre-subscription holdings,

\footnotetext{
301. Ibid., at para. I2.

302. See Kämpf, supra note 252 at I-2; Gala LARSEN and Sean GILBERT, “Asian Infrastructure Investment Bank Releases New Environmental and Social Standards” World Resources Institute (4 March 20I6).

303. See Larsen and Gilbert, supra note 302.

304. Humphrey, supra note I 6 at 4 .

305. Biswas, supra note I 55 at 3; Güven, supra note IO4 at 20; Strand et al., supra note 24 at 58-60 (arguing that changes to $\mathrm{WB}$ and $\mathrm{ADB}$ voting shares had minimal effect).

306. See also Strand et al., supra note 24 at 6I (in existing MDBs, this might have informed China's preference for special operations funds, which permit more direct control).

307. This would increase developing country board members. WB, "World Bank Doc. 3238 IV2", Attachment F (untitled, undated options paper), online: < http://documents.worldbank.org/curated/en/ 69476 I 468 I 4248538 I $/ \mathrm{pdf} / 3238$ Iov2.pdf $>$

308. See ibid., at paras. $13-\mathrm{I} 6$.

309. AIIB Agreement, art. 53(I).

3 го. Nelson and Weiss, supra note I60 at I; Davis and Wei, supra note I I 8; World Bank, supra note 307 at Attachment E. One Chinese commentator implies that China's one-party state would avoid such delays. See $\mathrm{Li}$ and Wan, supra note 2 at 25.

3II. See World Bank, supra note 307 at para. Io.
} 
requires unanimous approval at both the AIIB and the ADB. ${ }^{3 \mathrm{I} 2}$ However, the principle itself need not be amended to reallocate shares of one subscription increase. Certain members could simply waive preemptive rights for a given increase. ${ }^{313}$ This presupposes individual members' magnanimity, and at the AIIB and the ADB still presents a higher voting barrier than amending the Agreement, because in addition to agreements with rights-waiving members, a Super Majority vote is required to increase authorized capital stock. ${ }^{3 \mathrm{I}}$ Practically, however, the AIIB may have a safety valve, because votes to raise capital stock are likely to be less politically contentious, and, thanks to the AIIB's high initial paid-in capital ratio, ${ }^{315}$ small adjustments would not require costly investment by share-acquiring members.

Overall, while the AIIB updated the balance of voting shares, it has not addressed fundamental sources of representational inertia which, in part, led to its creation.

\section{CONCLUSION}

The AIIB and ADB feature largely similar organizational structures, and the AIIB has reproduced the status quo in three particularly important ways: First, its share allocation provisions updated voting shares to reflect current economic realities, but reproduced the huge voting gap which undermined smaller countries' satisfaction with incumbent MDBs. Second, China's de facto ability to select the President likewise reproduces an aspect highly unpalatable to borrowing countries. Third, although requiring a high proportion of paid-in capital theoretically allows some flexibility to later redistribute voting shares via subscription increases, the AIIB has not addressed fundamental limitations on institutional updating, should either of the two preceding provisions hamper AIIB functionality.

Beneath the AIIB and ADBs' overarching similarities, the AIIB is both more conservative and more liberal than its counterpart. In terms of membership, it is more conservative in favouring regional members by allotting a seventy-five percent voting share and eight out of twelve director seats, and in its meagre twelve percent basic share votes, even accounting for Founding Member votes. However, it is more liberal in permitting a simple majority to admit new members, and in providing eligibility to non-states.

Of the four areas surveyed, financing is where the AIIB appears most liberal. While requiring that twenty percent of subscribed capital be paid-in is higher than incumbent MDBs, it permits subscriptions entirely of callable capital until total capital reaches \$4oobn, without falling beneath the ADB's five percent paid-in capital ratio. This positions the AIIB to grow aggressively, though credit rating limitations might constrain this. Furthermore, the AIIB permits a much higher 2.5:I (loan/equity : subscribed

\footnotetext{
3 I 2. AIIB Agreement, arts. 5(4), 53(2)(iii); ADB Charter, arts. 5(2), 59(2)(iii). See Articles of Agreement of the International Finance Corporation, 264 UNTS I 8 (I955) (as amended), art. II, s. 2(d), art. VII(b)(ii); Reisen, supra note I at 299.

313. See World Bank, supra note 307 at attachment G.

3 I4. AIIB Agreement, art. 4(3); ADB Charter, art. 4(3).

3I 5 . See supra note 43 .
} 
capital) ratio. It is conservative in its apparent reticence for concessional lending and the related limits on loan proceed reinvestment. The AIIB's attitude toward equity investments, by contrast, is far more permissive than at the $\mathrm{ADB}$, in both the proportion of subscribed capital made available and the lack of a BG approval requirement. In addition, permitting share payments in ten instalments permits greater developing country participation, although China's retention of a veto over individual subscription increases is more conservative.

By contrast, the AIIB is most conservative in its approach to voting. In addition to the first two status quo provisions noted above, China may veto removal of the AIIB President. Allowing abstentions in BD voting, however, creates the possibility that large shareholders could yield their grip on that organ. Furthermore, the AIIB streamlined certain adjustments to the Agreement by permitting changes by Super Majority vote, though, as noted above, these changes are unlikely to resolve the voting provisions which borrowing countries fundamentally resent.

Analysis of governance yields mixed results. The non-resident BD is a bold step away from the status quo, especially combined with an AIIB President potentially able to unilaterally approve certain loans and remove staff members. The impact will depend on its implementation. It will hopefully result in significant efficiency gains. However, making the BD non-resident and unremunerated, and strictly limiting staff terms, sacrifices independence in favour of state control. Consequently, inefficiencies from increased politicization and unavoidable loss of expertise could thus offset efficiency gains in other areas.

AIIB operating principles improve upon ADB principles by allowing universal procurement, expressly requiring compliance with economic and social policies, and allowing loan disbursement before expenses are incurred. However, if improperly implemented, the latter could fuel corruption, while universal procurement could neglect domestic industries.

The AIIB adopted a very conservative stance regarding capacity-building efforts. It eschews "political considerations" and "interference" in its Agreement, largely omits capacity-building from its ESF, enables extensive hands-off equity investing, and, in seeking a "lean" institution, may find itself understaffed to provide technical assistance for which MDBs are often sought. Some of this may be counterbalanced by allowing country systems to assume a larger role in ESF implementation.

Overall, the AIIB is not a radical departure from the status quo, but its innovation will likely continue with the adoption of more specific policies. The way in which China wields its far-reaching control over the institution will determine whether now enthusiastic AIIB members later become disaffected. The AIIB's more promising innovations must be tested in practice before judgement is passed, but it is undeniable that the AIIB has pursued several notable institutional updates. It appears positioned, if deftly managed, to make a significant contribution to filling Asia's infrastructure deficit, and testing new approaches capable of yielding increased development returns. 